\title{
Mental health support services for medical students: a systematic review
}

\author{
Serviços de apoio à saúde mental do estudante de medicina: uma revisão sistemática
}

\author{
Maryana Guimarães de Morais ${ }^{1}$ (1) $\mid$ mguimaraes011@gmail.com \\ Isabella Morais Arantes de Oliveira e Silva' (D) bebellaarantes@gmail.com \\ Estela Ribeiro Versiani' (D) estela.versiani@gmail.com \\ Claudia Cardoso Gomes da Silva' (1) claudiacardoso.cpeq@gmail.com \\ Ana Socorro de Moura' (1) ana10escs@gmail.com
}

\begin{abstract}
Introduction: Considering the high prevalence of mental health problems among medical students, medical schools should be ethically committed to promote student's mental health, offering health services and prevention strategies.

Objective: The objective of this systematic review is to identify scientific publications on mental health services offered by Brazilian universities to medical students, as well as the professionals involved and the types of interventions most often offered.

Method: Systematic literature review, following the guidelines of the Preferred Reporting Items for Systematic Reviews and Meta-analysis (PRISMA). The Scielo, PubMed/Medline, Lilacs, ERIC, The Cochrane Library and CAPES databases were searched for studies published until August 2020, as well as theses and dissertations. The studies were screened, selected, analyzed and relevant data were extracted by two independent reviewers.

Results: 16 studies were included. The identified mental health services resort to different strategies towards a common goal of promoting medical students' mental health. The interventions most frequently found in these services are brief psychotherapy, psychiatric care, psychologicaleducational guidance and mentoring programs. Most services were created to attend medical students and some of these have been extended to other undergraduate students. In the analyzed services, there is a predominance of multidisciplinary teams, which differ regarding the number and categories of professionals involved.

Conclusion: Mental health support services for medical students in Brazil differ both in terms of how they work within the institutions and in terms of the involved professionals. It was observed that publications on these services are scarce when compared to the number of institutions that offer the undergraduate medical course in Brazil. Aiming to expand and consolidate actions aimed at promoting medical students' mental health in Brazilian higher education institutions, further research on this topic is required.
\end{abstract}

Keywords: Mental Health; Medical Students; Student Health; Mental Health Services.

\section{RESUMO}

Introdução: Considerando a alta prevalência de problemas de saúde mental entre estudantes de Medicina, as instituições que formam profissionais médicos têm o compromisso ético de se preocupar com a promoção da saúde mental de seu corpo discente, oferecendo serviços de apoio e desenvolvendo estratégias de prevenção.

Objetivo: Esta revisão tem como objetivo identificar publicações científicas sobre serviços de assistência oferecidos aos estudantes de Medicina nas instituições de ensino superior do Brasil, bem como informações sobre os profissionais que os compõem, o público-alvo atendido e os tipos de intervenção mais utilizados.

Método: Trata-se de revisão sistemática de literatura, orientada pelas diretrizes do Preferred Reporting Items for Systematic Reviews and Meta-Analysis (PRISMA). Foi realizada busca por estudos nas bases de dados SciELO, PubMed/Medline, Lilacs, ERIC, The Cochrane Library e Catálogo de Teses e Dissertações da Capes, sem delimitação de tempo, publicados até agosto de 2020. Em seguida, duas revisoras, de forma independente, selecionaram os estudos e extraíram os dados pertinentes para a construção desta revisão.

Resultado: Foram incluídos 16 estudos. Os serviços de apoio identificados atuam por meio de estratégias diversas com o objetivo comum de promoção da saúde mental do estudante. As intervenções mais encontradas nesses serviços são atendimento psicoterápico breve, atendimento psiquiátrico, orientação psicopedagógica e programas de mentoring. A maioria dos serviços foi implementada para atender estudantes de Medicina, e alguns ampliaram seu alcance a discentes de outros cursos de graduação. Em relação aos profissionais que compõem esses serviços, encontramos equipes multiprofissionais que variam em número e categorias profissionais envolvidas.

Conclusão: Os serviços de apoio destinados ao estudante de Medicina no Brasil apresentam diferenças tanto quanto à forma de atuação dentro das instituições como quanto aos profissionais envolvidos. Verificou-se que as publicações sobre esses serviços são escassas quando comparadas ao número de instituições que oferecem o curso de graduação em Medicina no Brasil. A fim de ampliar e consolidar ações voltadas para a promoção da saúde mental do estudante de Medicina dentro das instituições de ensino superior brasileiras, mais pesquisas sobre essa temática são necessárias.

Palavras-chave: Saúde Mental; Estudantes de Medicina; Saúde do Estudante; Serviços de Saúde Mental.

${ }^{1}$ Escola Superior de Ciências da Saúde, Brasília, Distrito Federal, Brazil.

Received on 09/24/20; Accepted on 03/08/21. | Evaluated by the double blind review process. 


\section{INTRODUCTION}

A high rate of mental disorders among medical students has been associated to a series of factors inherent both to the university context and the individuals themselves, who, upon entering undergraduate school, must deal with issues associated with adolescence, transition to the university, adapting to different learning methods and establishing new interpersonal relationships ${ }^{1-3}$.

In a systematic review study with a meta-analysis in 2017, the prevalence of several mental health problems in medical students in Brazil was verified, including depression, burnout, alcohol abuse and anxiety. Among these, the most prevalent, as well as in the general population, was anxiety, indicating that most medical students in the country have a tendency towards showing anxiety symptoms. The analysis also showed that the students' signs of depression, when stratified by severity, are predominantly mild².

A cross-sectional qualitative study, carried out by Tenório et al. in 2016, sought to assess the mental health of 78 students from two medical schools with different teaching and learning models, one of them with a traditional approach and the other structured as Problem-Based Learning (PBL). Using a semi-structured questionnaire and focal groups consisting of students, it was found that the educational process was associated with psychological distress in both groups, who reported motivations, course-related sources of stress, and similar relief factors ${ }^{4}$.

In this context, in which medical training is often associated with psychological and emotional disorders, the institutions that train medical professionals have an ethical commitment to be concerned with their students' mental health, offering prevention and care strategies in this area.

In Brazil, the concern of higher education institutions with their students' mental health status acquired greater relevance in the second half of the $20^{\text {th }}$ century, with the implementation of services that offered psychological assistance to university students. The first service created for this purpose was established in 1957 at Universidade Federal de Pernambuco and had medical students as the first recipients. In the same context, in the 1960s, federal universities in the states of Rio Grande do Sul, Minas Gerais and Rio de Janeiro also implemented mental health services for their students. Since then, several assistance projects aimed at promoting students' mental health have been implemented in higher education centers in Brazil ${ }^{5,6}$.

Aiming to guarantee the success of psychological and psychiatric assistance within the academic environment, the anonymity, independence and the principle of flexibility are considered the main characteristics that assistance services for university students must have. The confidentiality of the information shared during care, the independence of the service in relation to the teaching departments, with an assistance team not connected with the institution, and the flexibility of the type of care offered according to each individual's circumstances and identity contribute for these services to accomplish the care function with excellence and ethics ${ }^{7}$.

In 2016, at the 1st São Paulo Forum of Support Services for Medical Students, the "Carta de Marília" was created. In this document, created collectively by representatives of student support services, teachers and students, the responsibility of educational institutions in promoting and recovering the mental health of university students was highlighted. Among the actions that can contribute to this end, actions were elected, ranging from individualized care by qualified professionals to the promotion of cultural activities that go beyond the academic environment ${ }^{8}$.

However, challenges remain regarding the implementation and expansion of medical student assistance services, which already existed when these approaches were introduced. It has been verified that the current demands of medical schools in the country are associated to the adequacy of care to the individual assistance model and the application of new support strategies, such as the incentive to develop extracurricular activities ${ }^{9}$.

To contribute to the discussion regarding support services for medical students in Brazilian institutions, it is important to map and learn about existing publications on this type of service, as well as to understand how they work. Thus, we expect to offer subsidies for the improvement of the mental health promotion actions offered by the medical teaching center services and, ultimately, to collaborate for the quality of the care provided to the medical student.

In this sense, this study aims to identify scientific publications on the assistance services offered to medical students in higher education institutions in Brazil, as well as information on the professionals who comprise them, the intended target audience and the types of interventions most frequently used in these services.

\section{Review questions}

The following questions guided the research:

- What has been published about the mental health support services made available to students in higher education institutions that offer a medical course in Brazil?

- What are the strategies adopted by support services to promote mental health? 
- Which professionals are responsible for providing these mental health support services to the student?

\section{METHOD}

\section{Type of study}

This is a systematic literature review guided by the "Preferred Reporting Items for Systematic Reviews and Metaanalysis (PRISMA)" guidelines and carried out to identify studies that describe mental health support services provided to medical students, in the context of the Higher Education Institutions in Brazil.

\section{Inclusion and exclusion criteria}

All identified studies written in Portuguese, English or Spanish that addressed the existece of mental health support services for medical students in higher education institutions in Brazil, without time limits, but that were published by August 2020, which was the moment of the last search, were included in the review.

Studies dealing with interventions aimed at promoting medical students' mental health that had not been promoted by a service structured for this purpose were excluded, as well as studies of which access to the full text was not possible.

\section{Databases}

A systematic search was conducted based on articles and dissertations published in the following databases: Pubmed / Medline, Lilacs, The Cochrane Library, Scielo, ERIC and CAPES theses and dissertations catalog.

\section{Search Strategy}

The search strategy was defined based on an advanced search conducted on these bases, in order to include the largest number of relevant studies. The descriptors used as reference were "Serviços de apoio", "Saúde mental" and "Estudantes de medicina", as well as their English correspondents "Support services", "Mental health" and "Medical students". The search strategies were adapted for the different databases and are described in Chart 1.

\section{Study selection and data extraction}

All references found through the searches were organized using Mendeley Software ${ }^{10}$. Then, the Cochrane Collaboration's Covidence Platform for Systematic Review ${ }^{11}$ was used as a tool for the selection, screening and extraction of study data.

Study selection was independently carried out by two appropriately trained reviewers. The Covidence Platform provides an interface for each reviewer and then indicates which studies showed divergences in the analysis, so they can be resolved by a third reviewer. Initially, the title and summary of the selected texts were analyzed. Disagreements about the inclusion or exclusion of a particular study were analyzed by a third reviewer. After this stage, the evaluation of the complete texts and definition of the species that would constitute the review was carried out. Once again, in case of studies that showed divergences between the two main reviewers, the third reviewer resolved the conflicts.

Data were extracted from the included studies using data extraction tables, designed to meet the objectives of this review. The characteristics of the studies were taken from the abstracts and the full texts of the studies. Two reviewers independently extracted the data and, in cases of divergence, the data were analyzed by a third reviewer.

A total of 171 studies were found by searching the databases. In addition to these, another 20 articles were screened, identified in the references of selected studies.

Of the total of 191 selected studies, 57 were excluded by the Covidence platform itself because they were duplicates, leaving 134 studies to be screened based on their title and abstract. The full texts of 61 studies were assessed for eligibility, and after the exclusion of 45 for not meeting the inclusion criteria, the 16 included studies remained (Figure 1).

Chart 1. Search strategies

\begin{tabular}{|c|c|c|}
\hline Databases & Search strategies & $\begin{array}{l}\text { Total number of } \\
\text { studies found }\end{array}$ \\
\hline $\begin{array}{l}\text { PubMed/ } \\
\text { Medline }\end{array}$ & $\begin{array}{c}\text { ((((Support services) OR } \\
\text { (psychological support)) } \\
\text { AND (mental health)) AND } \\
\text { (medical students)) AND } \\
\text { (brazil) }\end{array}$ & 20 studies \\
\hline LILACS & $\begin{array}{c}\text { (tw:(Serviços de apoio )) } \\
\text { OR (tw:(apoio psicológico)) } \\
\text { OR (tw:(apoio )) AND } \\
\text { (tw:(mental health )) AND } \\
\text { (tw:(medical students )) }\end{array}$ & 31 studies \\
\hline $\begin{array}{c}\text { The Cochrane } \\
\text { Library }\end{array}$ & $\begin{array}{l}\text { \#1 (Support service) OR } \\
\text { (psychological support) } \\
\text { \#2 (mental health) \#3 } \\
\text { (medical students) \#4 } \\
\text { (brazil) \#5 (\#1 AND \#2 AND } \\
\text { \#3 AND \#4 AND \#5) }\end{array}$ & 63 studies \\
\hline ERIC & $\begin{array}{l}\text { "Support service" } \\
\text { "psychological support" } \\
\text { "mental health" "medical } \\
\text { students"“brazil" }\end{array}$ & 6 articles \\
\hline Scielo & $\begin{array}{l}\text { (ab:(* serviços de apoio)) } \\
\text { OR (apoio) OR (apoio } \\
\text { psicológico) AND (saúde } \\
\text { mental) AND (estudantes } \\
\text { de medicina) }\end{array}$ & 4 articles \\
\hline $\begin{array}{l}\text { CAPES } \\
\text { theses and } \\
\text { dissertations } \\
\text { catalog }\end{array}$ & $\begin{array}{c}\text { Serviços de apoio } \\
\text { OR apoio OR apoio } \\
\text { psicológico AND saúde } \\
\text { mental AND estudantes de } \\
\text { medicina }\end{array}$ & 47 articles \\
\hline
\end{tabular}


Figure 1. PRISMA Flow Diagram

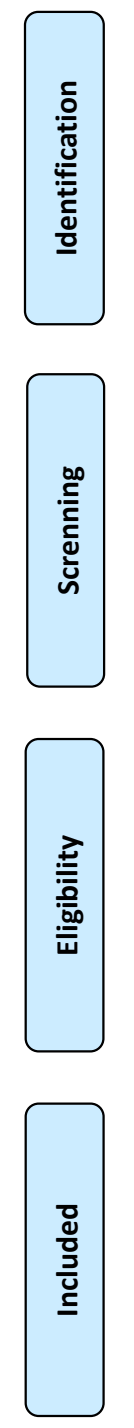

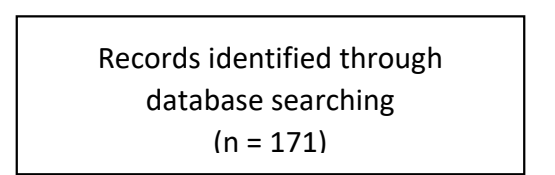

$(n=171)$
Additional records identified through other sources $(n=20)$
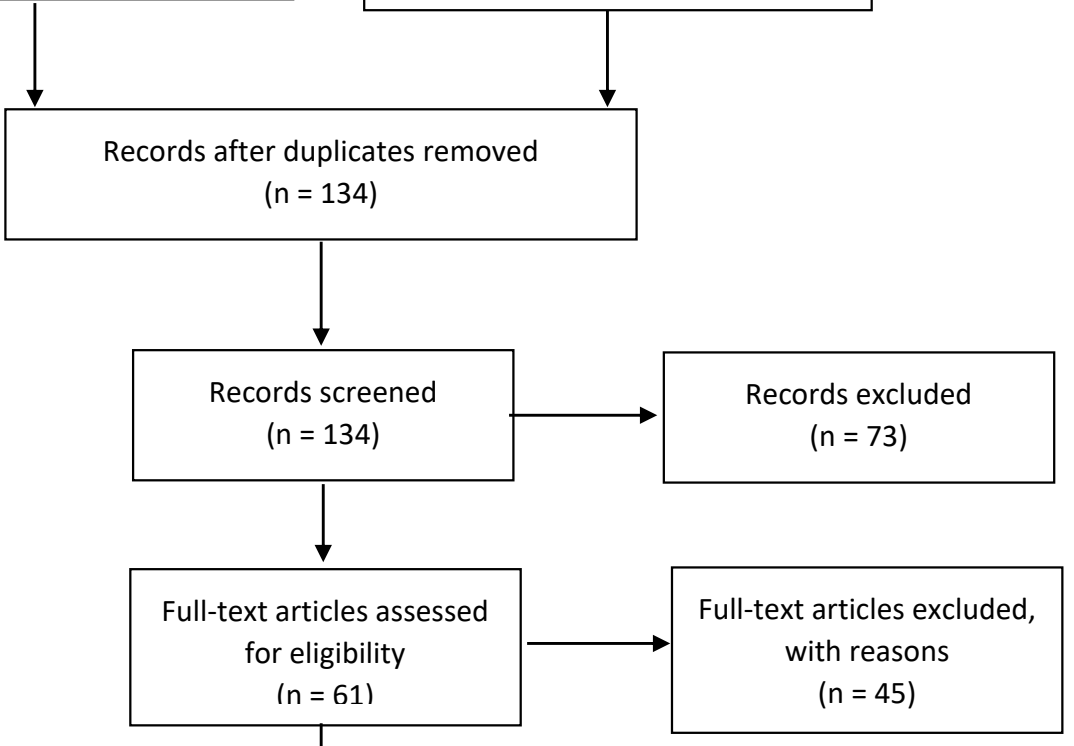

Studies included in qualitative synthesis $(n=16)$

\section{RESULTS AND DISCUSSION}

\section{Characteristics of included studies}

Based on the literature search, 16 studies were selected for the construction of this review. Of these, 13 are articles published in journals and three are dissertations presented at postgraduate programs of higher education institutions ${ }^{12-14}$. Regarding the methodological design of these studies, the predominant type was the documentary research of medical records and registration forms made available at the mental health support services. Other identified designs are experience reports ${ }^{15,16}$ and historical description ${ }^{17,18}$, in addition to qualitative research with the application of questionnaires ${ }^{19}$ and the phenomenological analysis of testimonials ${ }^{13,20}$.

All selected studies were carried out in Brazil, 14 of them involving higher education institutions in the Southeast region. Only two studies were carried out in other locations, one in an institution in the North region ${ }^{16}$ and the other in a higher education institution in the South region ${ }^{21}$. Thus, a concentration of publications on mental health support services for medical students in teaching centers in the Southeast region was verified. Moreover, it is noteworthy the scarcity of studies on this topic, especially when compared to the number of institutions offering undergraduate medical courses in Brazil - 287 public and private higher education institutions ${ }^{22}$.

The data show that 13 of the carried out studies took place in public institutions of higher education and that only three $21,23,24$ were carried out in private ones, which may possibly be the result of a policy of greater incentive to research in public institutions. Studies indicate that the public sector is more structured for performing research than the private sector, due to the educational policies historically adopted in the country. Although there has been greater incentive to private institutions in the last decade, this stimulus was not intended for research, but for professional training ${ }^{25}$.

Some mental health support services are described in more than one study, such as the Group of Psychological 
Assistance to Students of Faculdade de Medicina da Universidade de São Paulo (Grapal/FMUSP), addressed in two selected studies ${ }^{18,26}$; the Psychological and Psychiatric Assistance to Students of Universidade Estadual de Campinas (Sappe/ Unicamp), assessed in the studies by Campos $^{12}$ and Oliveira ${ }^{14}$; and the Educational and Psychological Support Center of Faculdade de Medicina de Ribeirão Preto (Caep/FMRP), also described in two studies ${ }^{15,17}$. This information corroborates the finding that studies on support services for medical students are concentrated in public teaching institutions in the Southeast region.

Finally, it is worth noting that the studies included in this review analyzed mainly the process of implementing the mental health support service, the characteristics of the offered service, the sociodemographic and clinical traits of the assisted audience, and the main reasons for seeking care in these services.

\section{Creation of services}

Each educational institution, when it creates a mental health support service for its students, seeks to meet the demands of their academic context. The Psychosocial Care Space (Epsico) of Universidade do Estado do Amazonas $(U E A)^{16}$ and the Psychological Assistance Project of Pontifícia Universidade Católica de Minas Gerais (APP/PUC Minas) ${ }^{23}$ are examples of cases in which the idea of offering strategies to promote mental health came from the management of the academic unit, after verifying situations of psychological distress among the students.

In both cases, the process was similar: faced with an increasing number of students with academic and psychosocial demands related to entering university and adapting to that scenario, a committee of teachers and managers was created to mobilize resources and strategies for the implementation of a student-oriented service.

In addition, it is worth noting that the performance of professors linked to the disciplines of psychiatry and medical psychology were important for the creation of support services in many institutions. The Caep of FMRP $^{17}$ and the Grapal of FMUSP ${ }^{18}$, were designed and sponsored by professors who were close to the medical students and understood the need to offer psychological assistance to this audience.

Considering these examples, the importance of the articulation between the academic community and the managers of the medical education institutions is observed in the implementation of support services to their students' mental health.

\section{Types of offered services and interventions}

The mental health support services described in the selected studies are mostly structured to offer a first embracement, such as individual psychological care for a short period of time, in cases of psychological distress related to personal and / or academic issues.

Most services have pre-established hours of operation, and the demand for care is due to spontaneous demand, without the need for prior scheduling. Only at the Epsico of UEA $^{16}$ and at the Student Support Center of Faculdade de Medicina da Universidade Federal de Minas Gerais (Napem/ UFMG $)^{27}$ - the service takes place, respectively, after scheduling by text messages or by filling out an enrollment form, in which the student previously informs the reason for the consultation.

After seeking care, the students usually undergo psychological screening, in which their main complaint or reason for seeking care is verified and the most appropriate intervention is defined. In the Mental Health Care Program (Proasme), implemented by Universidade Federal do Rio de Janeiro (UFRJ), for instance, this initial contact is called "Expanded Reception" and aims to carry out a situational diagnosis based on the assessment of the reasons that led the student to seek the service ${ }^{28}$.

It was observed that the offered psychological interventions are of different modalities, with a predominance of brief psychoanalytic psychotherapy. This type of intervention is characterized by a reduced number of consultations - from six to ten sessions - with each session lasting about 50 minutes. The main objective of brief psychotherapy is to allow the patient to acquire insight, that is, the knowledge of their psychological reality itself through the interpretation of the reports displayed during the assistance and their living contexts ${ }^{16}$.

In most studies, it is also emphasized that, in cases of more severe mental disorders or that require long-term approaches, the student is referred to psychological and/or psychiatric care not connected with the educational institution.

Therefore, it would be quite appropriate for the support services to be associated with or establish partnerships with the Psychosocial Care Network (RAPS), which is part of the Brazilian Unified Health System (SUS, Sistema Único de Saúde), in order to guarantee adequate assistance mainly to students recipients of affirmative actions and / or in situations of socioeconomic vulnerability, who cannot afford the costs of a private service.

Other examples of intervention modalities are the psychological-pedagogical or pedagogical guidance provided by the Grapal of FMUSP 18,26 and the prompt psychological assistance (PPA) offered at the Sappe of Unicamp ${ }^{12,14}$.

Some support services also have psychiatric care. In this case, the student can request this type of care exclusively or associated with psychological care, as in the Analytical Psychotherapy Service of the Psychiatric Clinic Outpatient Clinic of Hospital das Clínicas de Ribeirão Preto ${ }^{29}$. Only in the Emotional Reaguard for the Medical Student (Repam), a service of Faculdade 
de Ciências Médicas da Santa Casa de São Paulo, the prescription of medications by the psychiatrist is reported ${ }^{24}$. However, there are few services that offer this type of care, probably due to the lack of a psychiatrist working in these projects.

Tutoring or mentoring is another type of offered intervention, as in the Mentoring Program at UFMG ${ }^{20}$ and in the Mentoring Program of FMUSP ${ }^{19}$. According to a study published by Leão et al. in 2011, this type of assistance aims to offer a tutor (mentor) to accompany students throughout their training and to promote the exchange of experiences between teachers and students. In this sense, the students are divided into groups, which can vary between 12 to 14 people, with a tutor / teacher being responsible for each group. Regular meetings are held to discuss and guide about aspects related to the medical career and issues relevant to the students' personal life ${ }^{19}$.

Many services also work in the development of research and projects that aim to promote mental health within the academic environment and offer subsidies for the improvement of teaching inside the institution. As an example of this performance, we can mention programs that facilitate the student's integration into the university environment, developed by the Caep of FMRP ${ }^{15,17}$, and the scientific production of studies on the student population's needs. Also in this sense, Caep provides advice to the institution's Undergraduate Commission, to suggest and implement pedagogical proposals that associate medical training with the well-being of undergraduate students ${ }^{15,17}$.

Considering the analyzed data, it is possible to observe that the student support services described in the studies included in this review have the common objective of promoting medical students' mental health. However, they differ in terms of the offered intervention modalities - ranging from individual assistance to activities in other sectors of the institution -, demonstrating that there is not a single way to effectively address the issue of mental health in Higher Education Institutions. Chart 2 shows the main data collected from the studies included in this review.

\section{Target audience}

All the mental health support services described in the selected studies attend medical students. However, some of these services are also available to undergraduate students from other courses.

Overall, one can observe that most support services were implemented aiming at providing psychological and psychopedagogical assistance only to medical students, possibly due to the higher prevalence of mental disorders in this group, as shown by Pacheco et al. (2017). As an example, we have the Universidade do Oeste de Santa Catarina Student Support Service (Unoesc), implemented in 2004 to assist medical students ${ }^{21}$.

Chart 2. Main collected data.

\begin{tabular}{|c|c|c|c|c|c|}
\hline $\begin{array}{l}\text { Author(s)/ Year } \\
\text { of Publication }\end{array}$ & $\begin{array}{c}\text { Format/ } \\
\text { methodological } \\
\text { design }\end{array}$ & $\begin{array}{c}\text { Name of the Service/ Year } \\
\text { of Creation }\end{array}$ & Offered interventions & Target audience & $\begin{array}{l}\text { Professionals who } \\
\text { constitute the service }\end{array}$ \\
\hline $\begin{array}{l}\text { Fernandez } \\
\text { and Rodrigues } \\
\text { (1993) }\end{array}$ & $\begin{array}{l}\text { Article/ } \\
\text { Documental } \\
\text { research }\end{array}$ & $\begin{array}{l}\text { Analytical Psychotherapy } \\
\text { Service of the Psychiatric } \\
\text { Outpatient Clinic of Hospital } \\
\text { das Clínicas de Ribeirão } \\
\text { Preto, with the year of the } \\
\text { service implementation not } \\
\text { being informed. Assistance } \\
\text { to medical students started } \\
\text { in } 1983\end{array}$ & $\begin{array}{l}\text { Analytical psychotherapy } \\
\text { and psychiatric care }\end{array}$ & $\begin{array}{l}\text { Students from courses } \\
\text { offered by higher } \\
\text { education institutions } \\
\text { in São Paulo, among } \\
\text { them, Universidade } \\
\text { de São Paulo (USP). } \\
\text { stands out. The others } \\
\text { were not assessed. The } \\
\text { greatest demand is from } \\
\text { medical and psychology } \\
\text { undergraduate students. }\end{array}$ & $\begin{array}{l}\text { Resident physicians of } \\
\text { psychiatry, psychology } \\
\text { postgraduate students } \\
\text { and medical assistants } \\
\text { of the institution. }\end{array}$ \\
\hline $\begin{array}{l}\text { Cianflone et al. } \\
(2002)\end{array}$ & $\begin{array}{l}\text { Article/ Historical } \\
\text { Description }\end{array}$ & $\begin{array}{l}\text { Educational and } \\
\text { Psychological Support } \\
\text { Center (CAEP), } 1990\end{array}$ & $\begin{array}{l}\text { Brief psychotherapy, } \\
\text { psychopedagogical } \\
\text { guidance, professional } \\
\text { guidance, thematic and } \\
\text { reflection groups, family } \\
\text { guidance, guidance for } \\
\text { teachers, guidance and } \\
\text { referrals, pedagogical } \\
\text { advice to teachers and } \\
\text { pedagogical advice to the } \\
\text { Graduation Commission. }\end{array}$ & $\begin{array}{l}\text { Undergraduate medical } \\
\text { students from Faculdade } \\
\text { de Medicina de Ribeirão } \\
\text { Preto }\end{array}$ & $\begin{array}{l}\text { Psychologist, educator } \\
\text { and academic tech for } \\
\text { administrative support }\end{array}$ \\
\hline
\end{tabular}


Chart 2. (Continuation) Main collected data.

\begin{tabular}{|c|c|c|c|c|c|}
\hline $\begin{array}{l}\text { Author(s)/ Year } \\
\text { of Publication }\end{array}$ & $\begin{array}{c}\text { Format/ } \\
\text { methodological } \\
\text { design }\end{array}$ & $\begin{array}{l}\text { Name of the Service/ Year } \\
\text { of Creation }\end{array}$ & Offered interventions & Target audience & $\begin{array}{l}\text { Professionals who } \\
\text { constitute the service }\end{array}$ \\
\hline
\end{tabular}

Brief psychotherapeutic

care with limited time and objectives for students

Emotional Rearguard for the Medical Student, of

Bellodi (2007) Observational Faculdade de Ciências study

Médicas da Santa Casa de São Paulo (REPAM), 1997

Group of Psychological Assistance to Students of

Milian and Article/ Historical Faculdade de Medicina da Arruda (2008) Description Universidade de São Paulo (Grapal), created in 1983 and started em 1986 in crisis, referral to care not connected to the institution for individual long-term approaches with limited time, and psychiatric clinical care with the prescription of medications, if necessary.
Students from the

Medicine, Speech

Therapy and Nursing courses at Faculdade de

Medicina da Santa Casa de São Paulo
Psychologists, psychiatrists and secretaries
Psychological and psychiatric assistance to the student, brief preventive psychological interview with students in the first year of the course, organization of events to debate mental health services for students and advice to the family of attended students.
Medical students from Psychologists, FMUSP psychiatrists, secretary and coordinator
Group of Psychological Assistance to Students of Faculdade de Medicina da Universidade de São Paulo (Grapal), the year of creation is not informed.

\section{Marco (2009) Article/Essay}

Psychological and

Dissertation/ Psychiatric Assistance to Oliveira (2009) Documental Research Students of Universidade Estadual de Campinas (Sappe/Unicamp), 1987
Open service presentation interview for students in the first year of the course and psychopedagogical support.

\section{Brief psychoanalytic}

psychotherapy,

development of programs

that facilitate the student's

integration into the university context, prompt psychological assistance (PPA) and psychiatric clinical care.
Medica students from FMUSP
Not informed in the article
Students from the undergraduate and postgraduate courses offered by the higher education institution (Unicamp)
Psychologists and psychiatrists
Mental Health Service (MHS) and Mentoring Program; the years of creation of services are not Program

Psychological care and Observational

$\begin{array}{ll}\text { (2011) } & \text { Observat } \\ \text { study }\end{array}$ informed

Dissertation/

Souza (2011) Observational study
The name of the offered service was not informed: its year of creation was 1993 and its year of implantation was 1995
Dissertation/

Campos (2016) Documental Research
Psychological and Psychiatric Assistance to Students of Universidade Estadual de Campinas (Sappe/Unicamp), 1987
Psychological and Students from the

psychiatric care, social work, courses offered by the pedagogical proposals and institution and civil therapeutic groups with pre-defined subjects

Individual consultations

for embracement and screening, brief psychotherapeutic interventions with analytical guidance, association with networks and services internal and external to the college, individual, group and relational psychological assistance, prompt psychological assistance (PPA) and emergency psychiatric follow-ups
Medical, nursing and speech therapy students (undergraduate, graduate students and residents), professors and employees from different areas of Unicamp
The mental health service consists of psychologists and psychiatrists and the mentoring program has volunteer teachers who act as mentors.

Psychologists, psychiatrists and social servants (administrative workers technicians and teachers)
Psychiatrists and Psychologists 
Chart 2. (Continuation) Main collected data.

\begin{tabular}{|c|c|c|c|c|c|}
\hline $\begin{array}{l}\text { Author(s)/ Year } \\
\text { of Publication }\end{array}$ & $\begin{array}{c}\text { Format/ } \\
\text { methodological } \\
\text { design }\end{array}$ & $\begin{array}{c}\text { Name of the Service/Year } \\
\text { of Creation }\end{array}$ & Offered interventions & Target audience & $\begin{array}{l}\text { Professionals who } \\
\text { constitute the service }\end{array}$ \\
\hline $\begin{array}{l}\text { Martins and } \\
\text { Bellodi (2016) }\end{array}$ & $\begin{array}{l}\text { Article/ } \\
\text { Documental } \\
\text { Research }\end{array}$ & $\begin{array}{l}\text { The name of the offered } \\
\text { service was not disclosed; } \\
\text { it was created in } 2001\end{array}$ & Mentoring Program & $\begin{array}{l}\text { Third-year medical } \\
\text { students from } \\
\text { Universidade Federal de } \\
\text { Minas Gerais (UFMG) }\end{array}$ & $\begin{array}{l}\text { Team of mentors } \\
\text { (professions were not } \\
\text { informed) }\end{array}$ \\
\hline Pinho (2016) & $\begin{array}{l}\text { Article/ } \\
\text { Documental } \\
\text { Research }\end{array}$ & $\begin{array}{l}\text { Meio Oeste Catarinense } \\
\text { Psychological Assistance } \\
\text { Program, } 2004\end{array}$ & $\begin{array}{l}\text { Psychological care with } \\
\text { a cognitive-behavioral } \\
\text { approach and students' } \\
\text { referral for treatment with } \\
\text { supportive psychotherapy } \\
\text { not connected with the } \\
\text { institution }\end{array}$ & $\begin{array}{l}\text { In the year of its } \\
\text { implantation, it only } \\
\text { attended medical } \\
\text { students. In 2005, it } \\
\text { started to be offered to } \\
\text { all students of the other } \\
\text { courses offered by the } \\
\text { institution }\end{array}$ & $\begin{array}{l}\text { Not informed in the } \\
\text { article }\end{array}$ \\
\hline
\end{tabular}

Open embracement program, with preestablished opening hours, individual interviews aimed at making a situational diagnosis; the therapeutic proposals are diverse and established based on the contact with the student

Psychological screening,

brief psychotherapy, educational guidance (psychopedagogical and / or pedagogical), psychological counseling, mentoring program in the Mentoring category psychopedagogical and pedagogical guidance workshops, reflection groups and focal groups, consultancy services to the Graduation Commission and teachers of the institution

Murakami et al. Article/ Educational and (2018) Experience Report Psychological Support

Article/ (2019) Experience Report
Psychosocial Care Space (EPSICO), having been conceived and proposed in 2015 and implemented in 2018

\section{Brief psychotherapeutic} psychological assistance based on individual consultations; offer of professional internship in the field of psychology as of 2019
Students from the courses offered by the higher education institution (not informed in the analyzed article)
Psychologists and psychiatrists who perform interconsultations
At the time of its creation, it attended only medical students, being subsequently expanded to courses in physical therapy, speech therapy, nutrition, occupational therapy, biomedical informatics and biomedical science.
The students' psychosocial embracement was carried out through listening, brief psychotherapeutic care in cases of subjective urgency and referral to psychological care not connected with the institution for longitudinal follow-ups
Psychological Assistance to PUC Minas Students (APP),created in 2002
Students of the courses offered by the higher education institution

Students from the Institution
Three psychologists, a psychopedagogue, a pedagogue and an administrative technician
At the time of its creation, it had five psychologists and an occupational therapist. It currently consists of three psychologists

\section{FM-UFMG students}

Psychological interventions after the filling out of an enrollment

form by the student enrolled in medicine, speech therapy and radiology technology courses $\begin{array}{ll}\text { Ribeiro et al. } & \text { Article/ } \\ \text { (2019) } & \text { Documental }\end{array}$ Research

\section{Student}

Psychopedagogical UFMG (NAPEM), 2004 
With the expansion of the service and/or the implementation of other courses in the institutions, some mental health care services also started to attend students from other undergraduate courses, such as the Caep of FMRP, which, in 2002, started to meet the demands of other courses in the health area, such as Physical Therapy, Speech Therapy and Nutrition ${ }^{15}$. In only one of the included studies, the assessed service also attended students regularly enrolled in the institution's postgraduate program ${ }^{12}$.

\section{Professionals involved}

Mental health support services consist, in most cases, of multiprofessional teams that vary in number and in the involved professional categories.

Services that offer psychological and psychiatric care commonly consist of psychologists and psychiatrists. Teams may also include psychopedagogues, pedagogues, administrative technicians, secretaries and occupational therapists. The APP of PUC Minas ${ }^{23}$ and the Analytical Psychotherapy Service of the Psychiatric Outpatient Clinic of Hospital das Clínicas de Ribeirão Preto $^{29}$ also have interns from the Psychology undergraduate course and resident physicians in Psychiatry, respectively.

The tutoring or mentoring programs offered by the medical schools of USP ${ }^{19}$ and UFMG ${ }^{20}$, on the other hand, consist of teachers from the undergraduate course, usually on a voluntary basis.

In three of the included studies, there is no information about the professionals who constitute the assistance service ${ }^{21,26,27}$.

It is noteworthy that some services show some instability regarding the number of professionals. In the study that describes the Epsico of UEA, it is reported that, in 2015, the year the project was created, the service had five psychologists and an occupational therapist. However, in the year the article was prepared, in 2019, only three psychologists worked in the service ${ }^{16}$.

It can be assumed that the lack of a fixed professional staff is a factor that hinders the development of long-term projects, as well as the consolidation and expansion of mental health support services in Brazilian higher education institutions.

\section{FINAL CONSIDERATIONS}

The strengths of this review were the systematic and comprehensive search in the literature, as well as the knowledge gaps found based on the information collected from the included studies.

Considering the obtained results, it was observed that mental health support services addressed by the studies have the common objective of promoting mental health and, therefore, the medical student's quality of life. Different types of intervention, through individual and / or collective meetings, aim to welcome and support the students in their academic, psychological and social demands.

Most support services provide a first embracement to the student, set up as a listening space, and short-term interventions, with a predominance of brief psychotherapy. The access to these services depends, in general, on the university students' own initiative to seek them out, in the presence of any complication that might result in damage to their mental health.

However, some limitations were found when carrying out the study. Publications on student support services are scarce when compared to the number of institutions that offer an undergraduate medical course in Brazil. Moreover, the studies have a more descriptive character, when the ideal would be to have, in addition to the description, an assessment of the interventions offered by the support services, which would be more relevant than the experience reports.

Most of the available publications were carried out by public higher education institutions in the Southeast region, which makes it difficult to map and identify information about support services offered by institutions in other regions of the country.

The predominance of studies that report support services in public higher education institutions may suggest a publication bias. It is possible that other private teaching institutions have services for their students; however, for reasons not identified in this research, do not publish on the topic.

It is also important to highlight that the studies do not disclose the socioeconomic profile of the students assisted by the support services, nor is there mention of the presence of students who entered the university through the quota system or who are supported by the permanence policies. Knowledge about this profile would be important for the development of assistance strategies for students, especially to guarantee that the economically vulnerable group receive the adequate treatment follow-up.

Another limitation is the fact that most of the studies included in this review do not detail how to implement the services or how the proposed interventions are put into practice. Additionally, there was no information on possible difficulties in maintaining a multiprofessional team or on the impact of interventions on the attended students' mental health.

In addition, it is worth recognizing that many other actions aimed at promoting mental health are carried out in the academic environment by mental health fronts, leagues and other sectors unrelated to support services, and, therefore, were not part of this review.

As for the relationship between educational institutions and support services, it was observed that, despite their decisive role in the process of creating these services, there is no information in the studies regarding the participation of 
academic management at other times. It was not addressed, for instance, whether the teaching centers develop regular actions to promote mental health in the academic context, or whether there is a concern to carry out curricular and organizational changes aiming to meet the mental health demands.

Finally, although the main objective of this review was to map, through publications, the mental health support services that exist in higher education institutions in Brazil, one cannot infer that the services described in the included studies are still active. It is also possible that changes have occurred, both in the operation and composition of services.

These gaps indicate the need for more research on medical students' mental health care, as well as greater institutional incentive for the development of projects and studies with this focus. It is expected that, through further research on this topic, discussions on mental health can be expanded and strategies that prove to be effective can be implemented in students' support services, aiming to expand and consolidate the actions of these services in higher education institutions in Brazil.

\section{AUTHORS' CONTRIBUTION}

All authors contributed equally to the study design; creation of the protocol for reviewing search strategies; collection, analysis and interpretation of data; writing of the manuscript; critical review of the intellectual content and approval of the final version to be published.

\section{CONFLICTS OF INTEREST}

The authors declare no conflicts of interest in this study.

\section{FUNDING}

This research received support from the Institutional Program for Scientific Initiation Scholarships of the National Council for Scientific and Technological Development (PIBIC / CNPq) and by the Scientific Initiation Program of the School of Health Sciences (PIC / ESCS).

\section{REFERENCES}

1. do Amaral GF, Gomide LMP, Batista MP, Píccolo PP, Teles TBG, de Oliveira PM, et al. Sintomas depressivos em acadêmicos de medicina da Universidade Federal de Goiás: um estudo de prevalência. Rev Psiquiatr. Rio Gd Sul. 2008;30(2):124-30 [access in 24 jun 2020]. Available from: https://www. scielo.br/scielo.php?pid=S0101-81082008000300008\&script $=$ sci abstract\&tlng=pt.

2. Pacheco JP, Giacomin HT, Tam WW, Ribeiro TB, Arab C, Bezerra IM, et al. Mental health problems among medical students in Brazil: a systematic review and meta-analysis. Rev Bras Psiquiatr. 2017;39(4):369-78 [access in 24 jul 2020]. Available from: https://www.scielo.br/scielo.php?script=sci_ arttext\&pid=S1516-44462017000400369.
3. Quek TTC, Tam WWS, Tran BX, Zhang M, Zhang Z, Ho CSH, et al. The Global Prevalence of Anxiety Among Medical Students: A meta-analysis. Int J Environ Res Public Health. 2019 Jul 31;16(15):2735 [access in 27 jul 2020]. Available from: https://www.ncbi.nlm.nih.gov/pmc/articles/ PMC6696211/.

4. Tenório LP, Argolo VA, As HP, Melo EV, Costa EFO. Saúde mental de estudantes de escolas médicas com diferentes modelos de ensino. Rev Bras Educ Med. 2016;40(4):574-82. doi: 10.1590/1981-52712015v40n $4 \mathrm{e} 00192015$.

5. Cerchiari EAN, Caetano D, Faccenda O. Utilização do serviço de saúde mental em uma universidade pública. Psicol Ciênc Prof. 2005;25(2):252 65 [access in 10 jul 2020]. Available from: https://www.scielo.br/scielo. php?pid=S1414-98932005000200008\&script=sci_abstract\&tIng=pt.

6. de Assis $A D$, de Oliveira AGB. Vida universitária e saúde mental: atendimento às demandas de saúde e saúde mental de estudantes de uma universidade brasileira. Cadernos Brasileiros de Saúde Mental. 2010;2:159-77 [access in 31 jul 2020]. Available from: https://periodicos. ufsc.br/index.php/cbsm/article/view/68464/0.

7. Millan LR, De Marco OLN, Rossi E, de Arruda PCV. O universo psicológico do futuro médico: vocação, vicissitudes e perspectivas. São Paulo: Casa do Psicólogo; 1999.

8. Baldassin SP, Espin Neto J, Dagostino SB, Calado TBM, Guimarães KBS Colares MFA, et al. I Fórum Paulista de Serviços de Apoio ao Estudante de Medicina - Forsa Paulista - "A carta de Marília". Rev Bras Educ Med. 2016;40(4):537-9. doi: 10.1590/1981-52712015v40n4e00862016.

9. Nogueira JC. Saúde mental em estudantes do ensino superior: fatores protetores e fatores de vulnerabilidade [tese]. Lisboa: Universidade de Lisboa; 2017.

10. Elsevier. Mendeley - Reference Management Software and Researcher Network. Version 1803 [access in 18 sep 2020]. Available from: www. mendeley.com.

11. Veritas Health Innovation. Covidence systematic review software Melbourne, Australia [access in 20 sep 2020]. Available from: www. covidence.org.

12. Campos, CRF. Perfil sociodemográfico, clínico e acadêmico de estudantes universitários que passaram por atendimento psiquiátrico no Serviço de Assistência Psicológica e Psiquiátrica ao Estudante da Universidade Estadual de Campinas (Sappe-Unicamp) entre 2004 e 2011 [dissertação] Campinas: Universidade Estadual de Campinas; 2016 [access in 10 jul 2020]. Available from: http://repositorio.unicamp.br/jspui/bitstream/ REPOSIP/321049/1/Campos_ClaudiaRibeiroFranulovic_M.pdf.

13. de Souza GG. Atenção psicológica em universidade: a experiência de estudantes como clientes [dissertação]. Campinas: Pontifícia Universidade Católica de Campinas; 2011 [access in 10 jul 2020]. Available from: http://tede.bibliotecadigital.puccampinas.edu.br:8080/jspui/bitstream/ tede/271/1/Grasiela\%20Gomide\%20de\%20Souza.pdf.

14. Oliveira MLC. Caracterização sociodemográfica, acadêmica e clínica dos estudantes atendidos no Serviço de Assistência Psicológica e Psiquiátrica ao Estudante (Sappe) de 1987 a 2004 [dissertação]. Campinas: Universidade Estadual de Campinas; 2009 [access in 10 jul 2020]. Available from: http://repositorio.unicamp.br/jspui/handle/REPOSIP/308732.

15. Murakami K, Barros GC, Peres CM, Flauzino RH, Colares MFA. Atuações de um centro educacional e psicológico junto a estudantes universitários. Rev Bras Orientac Prof. 2018;19:109-19 [access in 10 jul 2020]. Available from: http://pepsic.bvsalud.org/scielo.php?script=sci_arttext\&pid=S1679$33902018000100012 \&$ lng=pt\&nrm=iso.

16. das Neves ALM, Ramos ES, Marangoni VL, Martins GC. Saúde mental e universidade: experiência do "Espaço de Atendimento Psicossocial" (Epsico) Trab En(Cena). 2019:4(2):531-42 [access in 31 jul 2020]. Available from: https:// sistemas.uft.edu.br/periodicos/index.php/encena/article/view/7482.

17. Cianflone ARL, Figueiredo JFC, Colares MFA. O Centro de Apoio Educaciona e Psicológico (Caep) da Faculdade de Medicina de Ribeirão Preto (USP): história e perspectivas. Medicina (Ribeirão Preto). 2002;35(3):392-6 [access in 31 jul 2020]. Available from: http://www.revistas.usp.br/rmrp/ article/view/857/869. 
18. Millan LR, de Arruda PCV. Assistência psicológica ao estudante de medicina: 21 anos de experiência. Rev Assoc Med Bras. 2008;54(1):904 [access in 31 jul 2020]. Available from: https://www.scielo.br/scielo. php?script=sci_arttext\&pid=S0104-42302008000100027.

19. Leão PBOS, Martins LAN, Menezes PR, Bellodi PL. Well-being and help-seeking: an exploratory study among final-year medical students. Rev Assoc Med Bras. 2011;4(57):379-86 [access in $1^{\circ}$ aug 2020]. Disponíve em: https://www.scielo.br/scielo.php?script=sci arttext\&pid=S0104-42302011000400009.

20. Martins AF, Bellodi PL. Mentoring: uma vivência de humanização e desenvolvimento no curso médico. Interface (Botucatu). 2016;20(58):71526 [access in $1^{\circ}$ aug 2020];20(58):715-26. Available from: https://www. scielo.br/scielo.php?pid=S141432832016000300715\&script $=$ sci abstract\&tlng=pt.

21. Pinho R. Caracterização da clientela de um programa de atendimento psicológico a estudantes universitários. Psicol Conoc Soc. 2016;6(1):11430 [access in $1^{\circ}$ aug 2020]. Available from: http://www.scielo.edu.uy/ scielo.php?script=sci_arttext\&pid=S1688-70262016000100006.

22. Brasil. Sistema e-MEC. Brasília: Ministério da Educação; 2020 [access in 16 aug 2020]. Available from: https://emec.mec.gov.br.

23. Mendes AA. A saúde mental de jovens universitários: apontamentos sobre a parceria de trabalho entre a APP-PUC Minas e o BAPU de Rennes na França. Pretextos - Revista da Gradução em Psicologia da PUC Minas. 2019;4(7):50-60 [access in 2 aug 2020]. Disponíve em: http://periodicos. pucminas.br/index.php/pretextos/article/view/20750/15015.

24. Bellodi PL. Retaguarda Emocional para o Aluno de Medicina da Santa Casa de São Paulo (Repam): realizações e reflexões. Rev Bras Educ Med. 2007;31:5-14 [access in 2 aug 2020]. Available from: https://www. scielo.br/scielo.php?pid=S0100-55022007000100002\&script $=$ sci abstract\&tlng=pt.
25. Hilu L, Gisi ML. Produção científica no Brasil: um comparativo entre as universidades públicas e privadas. X Congresso Nacional de Educação Educere; 2011. Curitiba: PUCPR; 2011. p. 7-10 [access in 2 aug 2020]. Available from: https://educere.bruc.com.br/arquivo/pdf2011/5221_3061.pdf.

26. De Marco OLC. O estudante de medicina e a procura de ajuda. Rev Bras Educ Med. 2009;33(3):476-81 [access in 2 aug 2020]. Available from: https://www.scielo.br/pdf/rbem/v33n3/19.pdf.

27. Ribeiro MMF, Melo JDC, Rocha AMC. Avaliação da demanda preliminar de atendimento dirigida pelo aluno ao Núcleo de Apoio Psicopedagógico ao Estudante da Faculdade de Medicina (Napem) da Universidade Federal de Minas Gerais. Rev Bras Educ Med. 2019:43:91-7 [access in $1^{\circ}$ aug 2020]. Available from: https://www.scielo.br/scielo.php?pid=S010055022019000500091\&script=sci_arttext.

28. Malajovich N, Vilanova A, FredericoC, CavalcantiMT, Velasco LB. Ajuventude universitária na contemporaneidade: a construção de um serviço de atenção em saúde mental para estudantes. Mental. 2017;11(21):356-77 [access in 3 aug 2020]. Available from: http://pepsic.bvsalud.org/scielo. php?script=sci_arttext\&pid=S1679-44272017000200005.

29. Fernandez JM, Rodrigues CRC. Estudo retrospectivo de uma população de estudantes de medicina atendidos no ambulatório de clínica psiquiátrica do Hospital das Clínicas da Faculdade de Medicina de Ribeirão Preto. Medicina (Ribeirão Preto). 1993;6(2):258-69 [access in $1^{\circ}$ aug 2020]. Available from: https://pesquisa.bvsalud.org/portal/resource/pt/lil-128945. 